\title{
Pharmacological Inhibition of the Skeletal IKK $\beta$ Reduces Breast Cancer-Induced Osteolysis
}

\author{
Silvia Marino ${ }^{1,2} \cdot$ Ryan T. Bishop ${ }^{1} \cdot$ Patrick Mollat $^{3} \cdot$ Aymen I. Idris $^{1,2}$
}

Received: 22 January 2018 / Accepted: 12 February 2018 / Published online: 17 February 2018

(C) The Author(s) 2018. This article is an open access publication

\begin{abstract}
IKK $\beta$ has previously been implicated in breast cancer bone metastasis and bone remodelling. However, the contribution of IKK $\beta$ expressed by bone cells of the tumour microenvironment to breast cancer-induced osteolysis has yet to be investigated. Here, we studied the effects of the verified selective IKK $\beta$ inhibitors IKK $\beta^{\mathrm{III}}$ or IKK $\beta^{\mathrm{V}}$ on osteoclast formation and osteoblast differentiation in vitro and in vivo, human and mouse breast cancer cells' support for osteoclast formation and signalling in vitro and osteolysis ex vivo and in immunocompetent mice after supracalvarial injection of human MDA-MB-231 conditioned medium or intra-cardiac injection of syngeneic $4 \mathrm{~T} 1$ breast cancer cells. Pre-treatment with IKK $\beta^{\mathrm{III}}$ or IKK $\beta^{\mathrm{V}}$ prior to exposure to tumour-derived factors from human and mouse breast cancer cell lines protected against breast cancerinduced osteolysis in two independent immunocompetent mouse models of osteolysis and the ex vivo calvarial bone organ system. Detailed functional and mechanistic studies showed that direct inhibition of IKK $\beta$ kinase activity in osteoblasts and osteoclasts was associated with significant reduction of osteoclast formation, enhanced osteoclast apoptosis and reduced the ability of osteoblasts to support osteoclastogenesis in vitro. When combined with previous findings that suggest NFKB inhibition reduces breast cancer tumorigenesis and metastasis our present findings have an important clinical implication on raising the possibility that IKK $\beta$ inhibitors, as bone anabolics, osteoclast inhibitors as well as anti-metastatic agents, may have advantages over anti-osteoclasts agents in the treatment of both skeletal and non-skeletal complications associated with metastatic breast cancer.
\end{abstract}

Keywords Osteolysis $\cdot$ IKK $\beta \cdot$ Osteoclast $\cdot$ Breast cancer $\cdot$ Bone $\cdot$ Osteoclastogenesis

\section{Introduction}

$\mathrm{NF \kappa B}$ is implicated in the development of breast cancer metastases [1-7] and its overexpression has been found to correlate with drug-resistance, resistance to radiotherapy and poor clinical outcome in breast cancer patients [8-11]. Many tumour- and bone-derived factors that have been implicated in the pathogenesis of breast cancer bone metastases

Aymen I. Idris

aymen.idris@sheffield.ac.uk

1 Department of Oncology and Metabolism, University of Sheffield, Medical School, Beech Hill Road, Sheffield S10 2RX, UK

2 Bone and Cancer Group, Edinburgh Cancer Research Centre, MRC Institute of Genetics and Molecular Medicine, University of Edinburgh, Edinburgh EH4 2XR, UK

3 Galapagos SASU, 102 Avenue Gaston Roussel, 93230 Romainville, France including receptor activator of NFKB ligand (RANKL) and interleukin-1 (IL-1) activate NFkB [12-14]. More recently, there has been increasing interest in the therapeutic targeting of IKK $\beta$, a key component of the canonical NFKB signalling pathway for the treatment of cancer-associated bone disease [14].

IKK $\beta$ plays a role in the regulation of bone remodelling [14-17]. Genetic inactivation or pharmacological inhibition of IKK $\beta$ inhibits osteoclastic bone resorption [1, 18-24] and promotes bone formation [25, 26]. IKK $\beta$ is also implicated in breast cancer bone metastasis [1] and we have recently reported that the indirect inhibition of IKK $\beta$-mediated NFKB activation by the TAK1 (TAK1, TGF-beta-activated kinase 1) inhibitor Celastrol or the NFKB inhibitor Parthenolide reduced the development of osteolysis in a model of breast cancer bone metastasis $[1,20,22,27]$. However, the effects of selective inhibition of IKK $\beta$ kinase activity on osteoblast and osteoclast changes associated with breast cancer bone metastasis have not been investigated. 
Using the two verified selective IKK $\beta$ inhibitors IKK $\beta^{\text {III }}$ and IKK $\beta^{\mathrm{V}}$ [28-30], we provide pharmacological evidence for the contribution of skeletal IKK $\beta$ to breast cancer-related bone cell activity and osteolysis. IKK $\beta^{\mathrm{III}}$ and IKK $\beta^{\mathrm{V}}$ protected against breast cancer-induced osteolysis in two immunocompetent mouse models of osteolysis and bone organ cultures derived from these mice. Further detailed functional and mechanistic studies showed that pre-exposure of osteoclasts and osteoblasts to these agents inhibited breast cancer cell-induced IKK $\beta$ activity and osteoclast formation and enhanced osteoblast differentiation. Based on these findings, we concluded that selective pharmacological inhibition of IKK $\beta$ signalling in the bone microenvironment might have a potential role in protecting the skeleton from the osteolysis associated with advanced breast cancer.

\section{Materials and Methods}

\section{Materials}

The selective IKK $\beta$ inhibitors IKK $\beta^{\text {III }}$ (401480) and IKK $\beta^{\mathrm{V}}$ (401482) were purchased from Calbiochem (Dorset, UK) and dissolved in dimethyl sulfoxide (DMSO) for in vitro and ex vivo studies. All solvents and reagents were purchased from Sigma-Aldrich (Dorset, UK) unless otherwise stated. Tissue culture medium was obtained from Invitrogen (Paisley, UK). Human macrophage colony-stimulating factor (M-CSF, 416-ML-050) was purchased from R\&D Systems (Abingdon, UK). RANKL was a gift from Patrick Mollat (Galapagos SASU, France) [16]. Foetal bovine serum (FBS) was obtained from GE Healthcare. Vitamin C (ascorbic acid) was obtained from BDH Laboratory Supplies (Dorset, UK). The following antibodies were used for Western blotting and immunostaining: anti-pIкB (ser32, 2859), anti-IкB (4812) from Cell Signalling Technology (Boston, MA, USA) and anti- $\beta$-actin (A5060) from Sigma-Aldrich (Dorset, UK).

\section{Cancer Cell Lines and Conditioned Medium}

Human MDA-MB-231 (MDA-231) and mouse 4T1 breast cancer cells were purchased from ATCC (Manassas, VA) and cultured in standard Dulbecco's modified essential medium (D-MEM) supplemented with $10 \%$ foetal calf serum (FCS), penicillin and streptomycin. For studies involving conditioned medium, cells were cultured in standard medium until $80 \%$ confluent. Cells were then cultured in serum-free medium and were allowed to grow for a further $16 \mathrm{~h}$ before conditioned medium was removed, filtered $(0.45 \mu \mathrm{m})$ and used fresh (10-20\% v/v).

\section{Animal Experimentation}

All procedures involving mice and their care were approved by and performed in compliance with the guidelines of Institutional Animal Care and Use Committee of University of Edinburgh (Scotland, UK). C57BL/6J and $\mathrm{BALB} / \mathrm{c}$ mice were obtained from Harlan (UK).

\section{Intra-tibial Injection of Tumour Cells}

Seven 4-week-old female BALB/c mice received intra-tibial injection cancer cells $\left(5 \times 10^{4}\right.$ cells/20 $\mu \mathrm{l}$ PBS $)$ in the left leg [31]. Animals were euthanised 14 days (4T1) post injection, and bones were analysed by micro-computed tomography (microCT, Bruker 1172 scanner).

\section{Supracalvarial Injection of Human MDA-231 Conditioned Medium}

The effects of human MDA-231 breast cancer-derived factors on osteolysis in vivo were studied by using the method described in [32]. Briefly, 3-week-old wild-type female C57B1/6 mice were injected over the calvarial bones with $50 \mu \mathrm{l}$ of human MDA-231 conditioned medium for 7 consecutive days. Mice were scarified 3 days after the last injection and the skull was fixed in $4 \%$ paraformaldehyde and bone density was assessed using micro-computed tomography (microCT; SkyScan 1172 scanner, SkyScan, Belgium) at a resolution of $5 \mu \mathrm{m}$. No mice injected with human MDA-231 conditioned medium in this study exhibited any obvious physical signs of illness or inflammatory response.

\section{The Calvarial Organ Culture}

The effects of human MDA-231 breast cancer or their derived factors on osteolytic bone damage ex vivo were studied by using an adaptation of the mouse calvarial organ culture previously described in [33]. Neonatal mouse calvarias were isolated from 7-day-old C57B1/6 mice, incubated in standard alpha-MEM for $24 \mathrm{~h}$ and divided into equal halves along the median sagittal suture. Each calvarial half was placed into culture on stainless steel rafts in 48 -well plates (Fig. 1a). Tissue culture medium was changed every $48 \mathrm{~h}$ and fresh control medium containing test agents and conditioned medium form human MDA231 cells $(20 \% \mathrm{v} / \mathrm{v})$ was added and the cultures were terminated after 7 days. At the end of the cultures calvarial bone density was assessed using micro-computed tomography 
Fig. 1 Inhibition of IKK $\beta$ reduces breast cancer-induced osteoclastogenesis and osteolysis. a Graphic representation of mouse calvaria organ co-culture system. b Total bone volume in mouse calvaria bone after exposure $\mathrm{CM}$ from human MDA-231 and mouse $4 \mathrm{~T} 1$ breast cancer cells in the presence and absence of vehicle or the selective IKK $\beta$ inhibitors IKK $\beta^{\text {III }}$ or IKK $\beta^{\mathrm{V}}(10 \mu \mathrm{M})$. c Representative photomicrographs of microCT scan of mouse calvaria bone from the experiment described in $\mathbf{a}$, b. d Graphic representation of supracalvarial injection in adult immunocompetent mice. e Total bone volume (BV/TV,

$\%$ ) in mouse calvaria bone after exposure to $\mathrm{CM}$ from human MDA-231 breast cancer cells in the presence and absence of vehicle or the selective IKK $\beta$ inhibitor IKK $\beta^{\text {III }}(20 \mathrm{mg} / \mathrm{kg}$ / day) from the experiment described in panel $\mathbf{d}(n=7)$. Data are mean $\pm \mathrm{SD}, * * p<0.01$ from vehicle
A

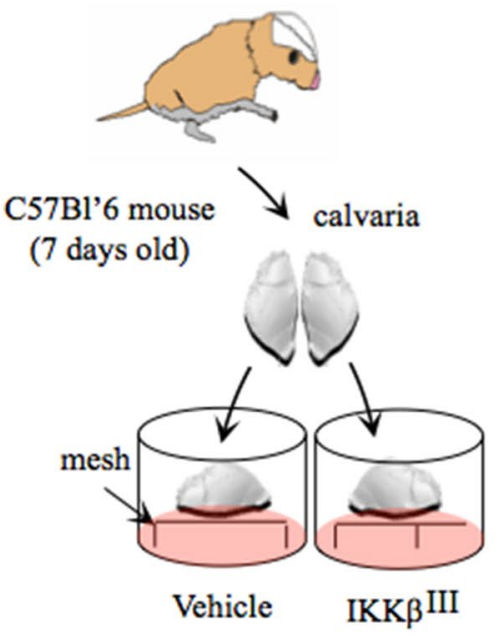

C

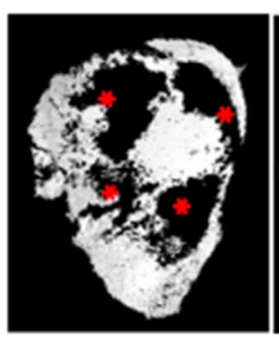

Vehicle

D

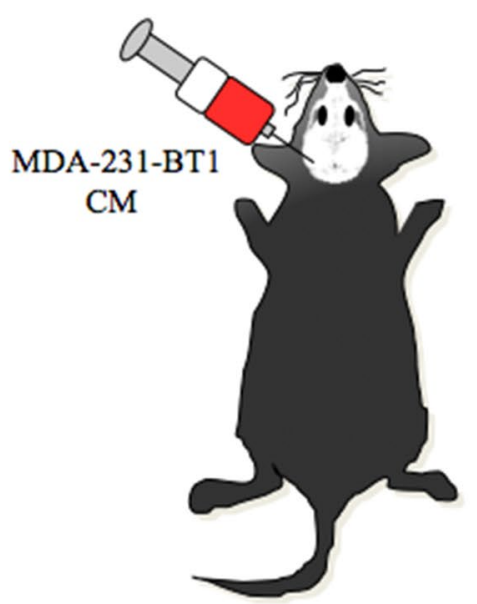

C57BL/6J immunocompetent mouse

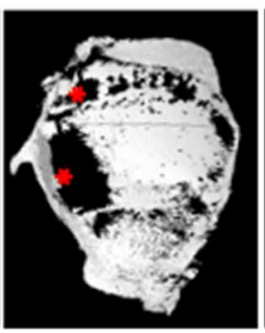

IKK $\beta$ III

B
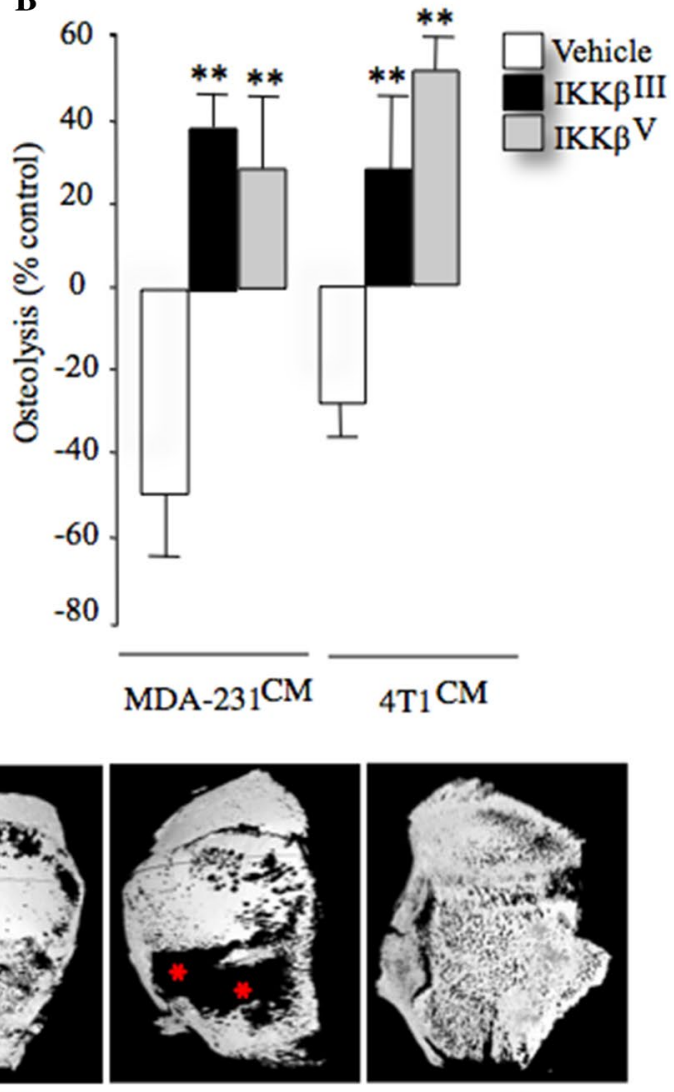

Vehicle

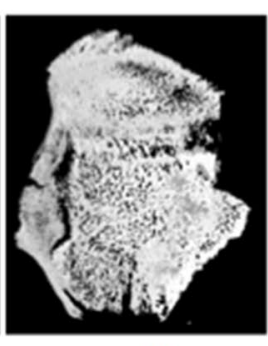

$\operatorname{IKK} \beta \mathrm{V}$

$\mathbf{E}$

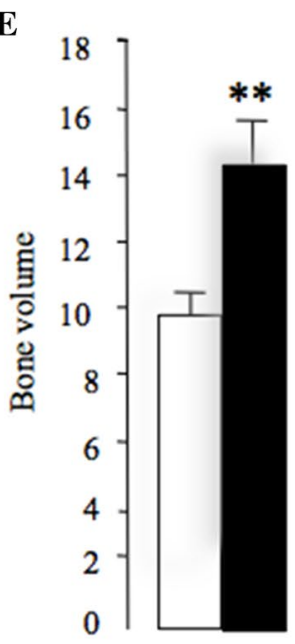

$\square$ Vehicle IKK $\beta$ III

( 3 weeks old)

(microCT; Bruker 1172 scanner, SkyScan, Belgium) at a resolution of $5 \mu \mathrm{m}$ as described in [34].

\section{Bone Histomorphometry}

Bones were fixed in buffered $4 \%$ formaldehyde for methyl methacrylate embedding without decalcification.
Tartrate-resistant acid phosphatase (TRAcP) staining was used to evaluate osteoclast parameters and toluidine blue staining for osteoblasts. Histomorphometric measurements were carried out on 5- $\mu$ m-thick sections, with an interactive image analysis system (IAS 2000, Delta Sistemi, Rome, Italy). Nomenclature, symbols and units of morphometric bone variables were used as previously described [35]. 


\section{Osteoblast Cultures}

Primary osteoblasts were isolated from the calvarial bones of 2-day-old mice by sequential collagenase digestion as previously described [36]. Osteoblasts were maintained in alpha-MEM supplemented with $10 \%$ FCS and left to adhere overnight. For bone nodule assay, osteoblasts were seeded into 12 -well plates at $10 \times 10^{5}$ cells per well in alpha-MEM, supplemented with $10 \%$ FCS, penicillin and streptomycin, $\beta$-glycerol phosphate $(10 \mu \mathrm{M})$ and $\mathrm{L}$-ascorbic acid $(50 \mu \mathrm{g} /$ $\mathrm{ml})$. The cells were cultured for up to 21 days with replacement of the culture medium in the presence or absence of test substances every $48 \mathrm{~h}$. At the end of the culture period, osteoblast number, differentiation and bone nodule formation were determined by Alamar Blue assay [37], alkaline phosphatase (Alk Phos) assay and alizarin red (ALZ) staining [38].

\section{Osteoclast Cultures}

Osteoclast formation, survival and activity were studied using RANKL- and M-CSF-generated mouse osteoclasts and bone

marrow cell-osteoblast co-cultures as previously described in [39]. Briefly, bone marrow (BM) cells were flushed from the long bones of 3-4-month-old mice and were plated into Petri dishes and incubated for $48 \mathrm{~h}$ in standard alpha-MEM supplemented with mouse M-CSF (100 ng/ml). Erythrocytes were removed and the adherent cells were washed with phosphate-buffered saline (PBS) and re-suspended in culture medium and counted. For osteoclast generation, the resulting M-CSF-generated bone marrow macrophages (osteoclast precursor cells) were plated into tissue culture plates (96-well plates, $15 \times 10^{3}$ cells/well; 12 -well plates, $150 \times 10^{3}$ cells/well) in standard alpha-MEM supplemented with M-CSF $(25 \mathrm{ng} / \mathrm{ml})$ and RANKL $(100 \mathrm{ng} / \mathrm{ml})$ or in the presence of calvarial osteoblasts $\left[8 \times 10^{3}\right.$ cells/well in $150 \mu \mathrm{l}$ of standard alpha-MEM containing $1,25-(\mathrm{OH})_{2}$-vitamin $\mathrm{D}_{3}$ $(10 \mathrm{nM})]$. For studies involving tumour-derived factors, conditioned medium from these cultures was prepared as described above then added to osteoclast cultures at a concentration of $10 \%(\mathrm{v} / \mathrm{v})$ in standard alpha-MEM. The cultures were terminated by fixation in $4 \%$ paraformaldehyde and washed with PBS. TRAcP staining was used to identify multinucleated osteoclasts and TRAcP-positive cells with three or more nuclei were considered to be osteoclasts and manually counted on a Zeiss Axiovert light microscope using a $10 \times$ objective lens.

\section{TUNEL Assay}

Briefly, adherent and non-adherent osteoclasts were collected, fixed with $4 \%$ paraformaldehyde and cytospun into glass slides. Apoptosis was identified on the basis of characteristic changes nuclear morphology using TUNEL staining as previously described [40]. Cells were counterstained with 4,6-diamidino-2-phenylindole (DAPI, $1 \mu \mathrm{g} / \mathrm{ml}$ ) for $3 \mathrm{~min}$ prior to analysis by fluorescence microscopy. Cells were scored as apoptotic on the basis of nuclear morphology. An average of five microscopic fields per treatment group was analysed ( $\times 200$ magnification).

\section{Caspase Assay}

Caspase-3/7 activation was measured using Apo-ONE® Homogeneous Caspase-3/7 Assay (Promega, UK), according to the manufacturer's instructions.

\section{Quantitative PCR}

Quantitative PCR (qPCR) was used to measure mRNA expression. mRNA was isolated and quantified using a NanoDrop (Thermo Scientific), and complementary DNA (cDNA) was generated using Invitrogen SuperScript III Reverse Transcriptase kit according to manufacturer's instructions. Primers for mouse RANKL (forward primer: 5'-TGAAGACACACTACCTGACTCCTG-3', reverse primer 5'-CCACAATGTGTTGCAGTTCC-3'); mouse OPG (forward primer: 5'-ATGAACAAGTGGCTGTGCTG-3', reverse primer 5'-CAGTTTCTGGGTCATAATGCAA-3') and mouse GAPDH (forward primer: 5'-CCTGAATTTTAA GCTACACACAGC-3', reverse primer 5'-CTGGCACTG CACAAGAAGAT-3') were designed using the Ensembl genome browser and Roche website. Gene expression was expressed as copy number per microgram of total RNA, and GAPDH was used for cDNA normalisation.

\section{Western Blotting}

Western blot analysis was used to detect protein expression and phosphorylation in cultured breast cancer and bone cells. Briefly, cells were seeded in 12-well plates and maintained in standard media until confluent. Prior to stimulation with test agents or vehicle, cells were incubated in serumfree alpha-MEM medium for $60 \mathrm{~min}$ (osteoclast cultures) or $16 \mathrm{~h}$ (osteoblast cultures). Test agents or vehicle were prepared in serum-free media and were then added for the desired period of time. The cells were then gently scraped in standard lysis buffer $(0.1 \%(\mathrm{w} / \mathrm{v}) \mathrm{SDS}, 0.5 \%(\mathrm{w} / \mathrm{v})$ sodium deoxycholate, $1 \%$ Triton X-100, $1 \mu \mathrm{M}$ EDTA, $2 \%$ (v/v) protease inhibitor cocktail, $10 \mu \mathrm{M}$ of sodium fluoride and $2 \%$ $(\mathrm{v} / \mathrm{v})$ phosphatase inhibitor cocktail. The lysate was incubated on ice for $10 \mathrm{~min}$ and centrifuged at $4{ }^{\circ} \mathrm{C}$ for $5 \mathrm{~min}$. Protein concentration was determined using BCA assay (Pierce, USA). Total protein (30-70 $\mu \mathrm{g})$ was resolved by SDS-PAGE on $12 \%$ polyacrylamide SDS gels, transferred 
onto PVDF membranes (Bio-RAD, UK) and immunoblotted with appropriate antibodies according to manufacturer's instructions. The immunocomplexes were visualised by an enhanced chemiluminescence detection kit (Pierce, USA) using horseradish peroxidase-conjugated secondary antibody (Jackson labs, UK), and then visualised using chemiluminescence (Amersham, UK) on a Syngene Gene Gnome imaging system.

\section{Statistical Analysis}

Data are presented as mean \pm standard deviation (SD). Statistical comparisons were performed using unpaired twosided Student's $t$ test, or analysis of variance (ANOVA) followed by Dunnett's post hoc test (SPSS, V11, IBM, USA). A $p$ value of 0.05 or below was considered statistically significant.

\section{Results}

\section{Bone-Autonomous Inhibition of IKK $\beta$ Suppresses Breast Cancer-Related Osteolysis}

We investigated whether pharmacological inhibition of IKK $\beta$ in bone cells affects osteolysis induced by tumourderived factors. Exposure of calvaria organ cultures derived from immunocompetent mice to conditioned medium from human MDA-231 or mouse 4T1 breast cancer cells (Fig. 1a) caused significant osteolytic bone damage when compared to control. These effects were completely abolished in the presence of the selective IKK $\beta$ inhibitors IKK $\beta^{\mathrm{III}}$ or IKK $\beta^{\mathrm{V}}$ $(1 \mu \mathrm{M})$ (Fig. 1b, c, $p<0.01$ ). Interestingly, pre-treatment of calvaria organ culture with the selective IKK $\beta$ inhibitors IKK $\beta^{\mathrm{III}}$ or IKK $\beta^{\mathrm{V}}$ caused a significant increase in bone volume when compared to vehicle control. Next, we took advantage of an in vivo supracalvarial injection mouse model to assess osteolysis in response to MDA-231 conditioned medium in adult immunocompetent mice (Fig. 1d). Administration of the selective IKK $\beta$ inhibitors IKK $\beta^{\mathrm{III}}$ $(20 \mathrm{mg} / \mathrm{kg} / \mathrm{day})$ into mice one day prior to injection of conditioned medium from human MDA-231 (Fig. 1d) caused a significant increase of bone volume when compared to control mice (Fig. 1e, $p<0.01$ ).

\section{Inhibition of IKK $\beta$ Reduces Breast Cancer-Induced Osteoclastogenesis}

Next, we tested the effects of pharmacological inhibition of IKK $\beta$ on breast cancer-induced osteoclastogenesis in vitro. As shown in Fig. 2a, exposure of mouse M-CSF

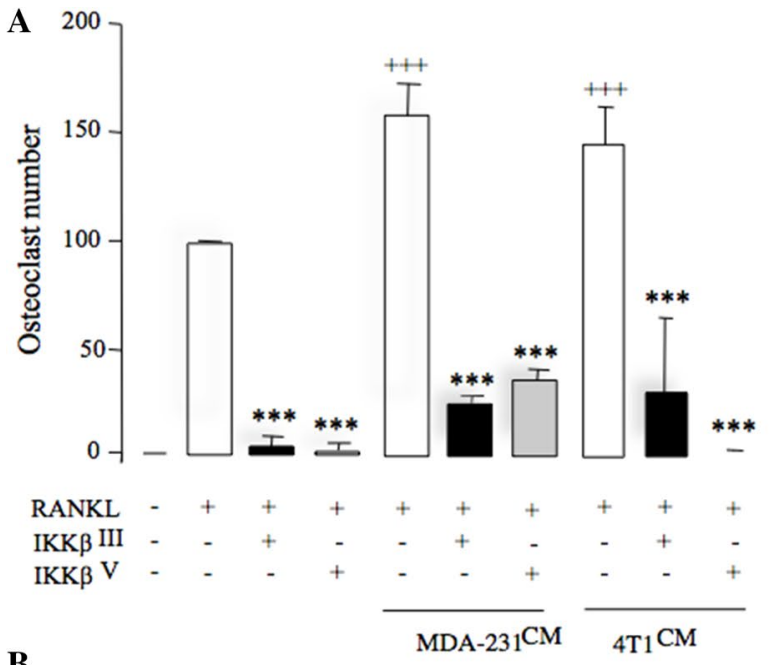

B
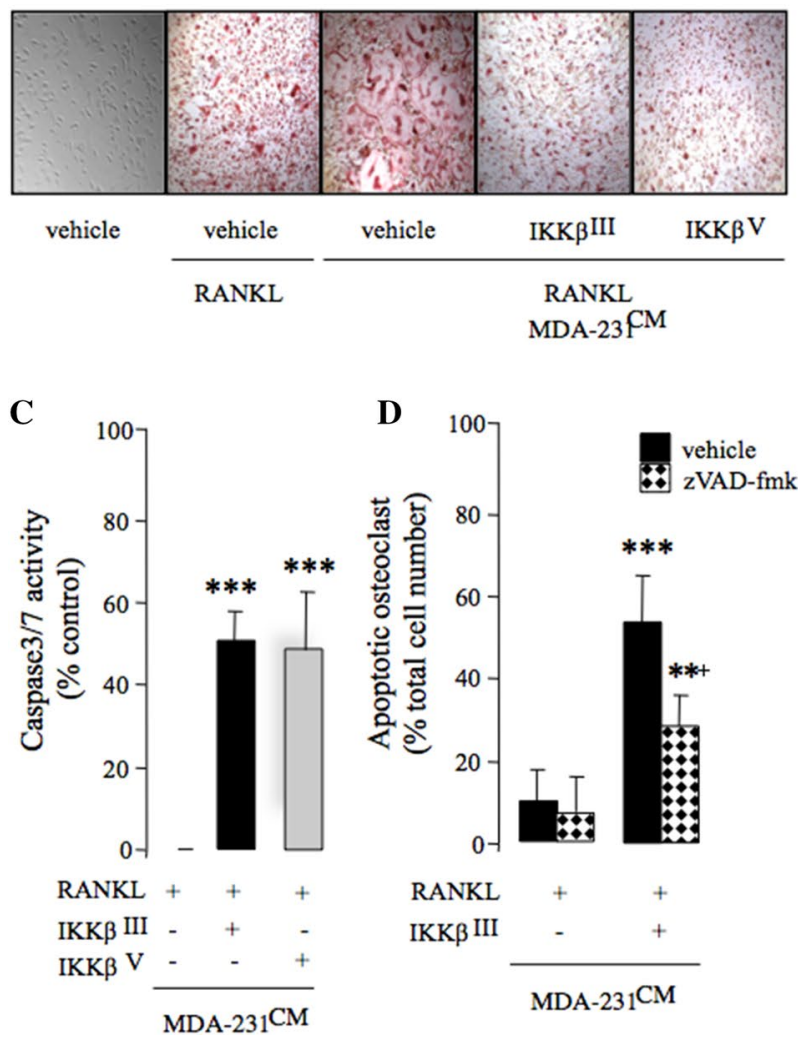

Fig. 2 Inhibition of IKK $\beta$ prevents RANKL and breast cancer cellinduced osteoclastogenesis. a Number of osteoclasts in mouse M-CSFdependent pre-osteoclast cultures after exposure to RANKL (100 ng/ $\mathrm{ml})$ and/or CM from human MDA-231 breast cancer cells $(20 \% \mathrm{v} / \mathrm{v})$ in the presence of vehicle $(0.01 \%$ DMSO) or the selective IKK $\beta$ inhibitors IKK $\beta^{\text {III }}$ or IKK $\beta^{\mathrm{V}}(3 \mu \mathrm{M})$. b Representative photomicrographs of M-CSFdependent pre-osteoclasts and TRAcP-positive multinucleated osteoclasts from the experiment described in panel a. c In vitro osteoclast apoptosis as evidenced by caspase-3/7 activation in M-CSF- and RANKL-generated mature osteoclast cultures treated with $\operatorname{IKK} \beta^{\mathrm{III}}$ or IKK $\beta^{\mathrm{V}}(10 \mu \mathrm{M})$ after $6 \mathrm{~h}$. d In vitro osteoclast apoptosis as evidenced by DNA fragmentation in M-CSF- and RANKL-generated mature osteoclast cultures treated with IKK $\beta^{\mathrm{III}}(10 \mu \mathrm{M})$ in the presence or absence of the caspase inhibitor zVAD-fmk $(10 \mu \mathrm{M})$ after $24 \mathrm{~h}$. Values are mean $\pm \mathrm{SD} ; * * p<0.05$ and $* * * p<0.001$ from vehicle; ${ }^{+++} p<0.001$ from RANKL treated; ${ }^{+} p<0.05$ from IKK $\beta^{\mathrm{III}}$ plus caspase inhibitor zVAD-fmk 
generated osteoclast precursors to conditioned medium from breast cancer cells MDA-231 and 4T1 (20\% v/v) enhanced RANKL-induced osteoclast formation $(p<0.001)$, and these effects were significantly reduced by the selective IKK $\beta$ inhibitors IKK $\beta^{\mathrm{III}}$ or IKK $\beta^{\mathrm{V}}(3 \mu \mathrm{M})$. Representative photomicrographs of osteoclasts from the experiment described are shown in Fig. 2b. None of these compounds affected the growth of M-CSF generated osteoclast precursors at the concentration tested (data not shown), thereby excluding the possibility that the inhibitory effect on osteoclast formation was mediated by a reduction in pre-osteoclast cell number. To investigate the effects of pharmacological inhibition of IKK $\beta$ on osteoclast survival in the presence of breast cancer-derived factors, we generated mature osteoclasts and exposed these cells to the selective IKK $\beta$ inhibitors IKK $\beta^{\mathrm{III}}$ or IKK $\beta^{\mathrm{V}}(10 \mu \mathrm{M})$ in the presence and absence of conditioned medium from human MDA-231 cells. IKK $\beta^{\text {III }}$ or $\operatorname{IKK} \beta^{\mathrm{V}}(10 \mu \mathrm{M})$ induced caspase-3/7 activation in mature osteoclasts within 6 h (Fig. 2c) and caused osteoclast apoptosis after $24 \mathrm{~h}$ (Fig. 2d), as evident by nuclear condensation and DNA fragmentation as measured by DAPI and TUNEL assays, respectively. Osteoclast apoptosis in these cultures was inhibited in the presence of the Caspase inhibitor zVAD-fmk (Fig. 2d), indicative of caspase involvement.

\section{Inhibition of IKK $\beta$ Reduces Breast Cancer-Associated Osteoblast Support for Osteoclastogenesis}

Osteoblasts enhance breast cancer-induced osteoclastogenesis by secreting various osteoclastic factors such as RANKL [41-43]. In this study, we tested the effects of IKK $\beta$ inhibition on osteoblast support for osteoclastogenesis in the presence of conditioned medium from the human MDA231 breast cancer cells. Pre-treatment of calvarial osteoblasts with the selective IKK $\beta$ inhibitors IKK $\beta^{\mathrm{III}}$ or IKK $\beta^{\mathrm{V}}$ $(3 \mu \mathrm{M})$ prior to the addition of mouse bone marrow cells and conditioned medium from the human MDA-231 (20\% $\mathrm{v} / \mathrm{v}$ ) inhibited osteoclast formation from bone marrowderived osteoclast precursors (Fig. 3a) and significantly reduced mRNA expression of RANKL (Fig. 3b, left) and OPG (Osteoprotegerin, Fig. 3b, right). Collectively, these results demonstrate that selective IKK $\beta$ inhibition in calvarial osteoblasts disrupts the ability of breast cancer cells to enhance osteoclastogenesis in the model described.

\section{Inhibition of IKK $\beta$ in Osteoblasts Increases Alkaline Phosphatase Activity}

$\mathrm{NF \kappa B}$ is implicated in the regulation of osteoblast differentiation and bone formation [25]. With this in mind, we examined the effects of the selective IKK $\beta$ inhibitors IKK $\beta^{\text {III }}$ or IKK $\beta^{\mathrm{V}}$ on osteoblast proliferation and differentiation in the presence of conditioned medium from human MDA-231
A Osteoclast count B RANKL OPG

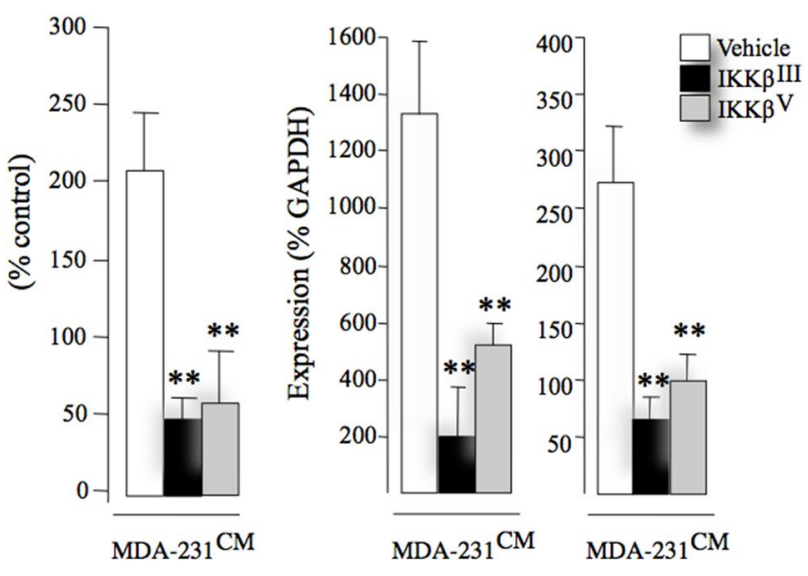

C Alk Phos activity

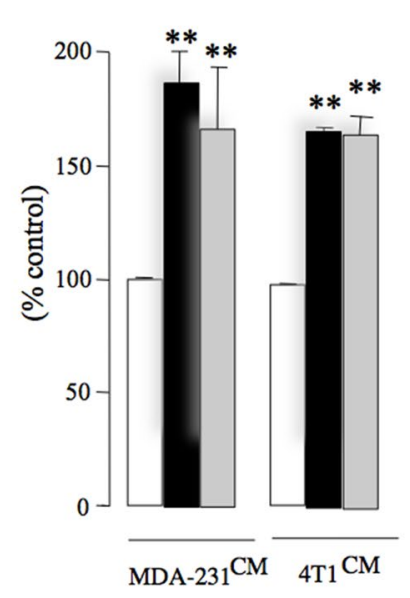

D Bone nodule formation

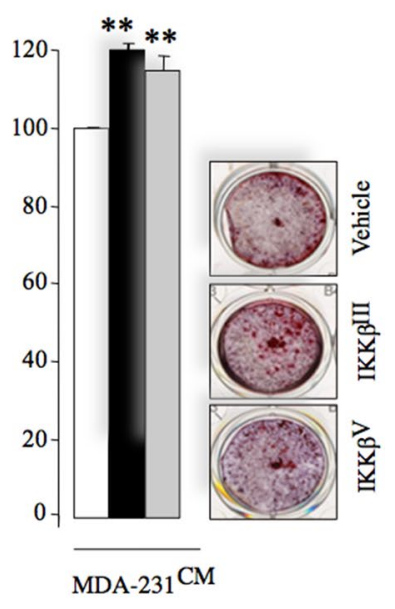

Fig. 3 Inhibition of IKK $\beta$ enhances osteoblast maturation and reduces their support for osteoclastogenesis. a Number of osteoclasts in mouse osteoblasts-bone marrow cell cultures after exposure to $\mathrm{CM}$ from human MDA-231 breast cancer cells in the presence of vehicle $\left(0.01 \%\right.$ DMSO) or the selective IKK $\beta$ inhibitors IKK $\beta^{\text {III }}$ or $\operatorname{IKK} \beta^{\mathrm{V}}(3 \mu \mathrm{M})$. The average number of osteoclasts in vehicle-treated cultures in three independent experiments is $45 \pm 6,51 \pm 12$ and $72 \pm 6$ osteoclasts/well. b The mRNA expression of RANKL (left) and OPG (right) in mouse calvarial osteoblasts after exposure to $\mathrm{CM}$ from human MDA-231 breast cancer cells in the presence of vehicle $\left(0.01 \%\right.$ DMSO) or the selective IKK $\beta$ inhibitors IKK $\beta^{\mathrm{III}}$ or IKK $\beta^{\mathrm{V}}$ $(10 \mu \mathrm{M})$. c, d Alkaline phosphatase activity (Alk Phos, c) and bone nodule formation (ALZ, d) in mouse calvarial osteoblasts after exposure to CM from human MDA-231 breast cancer cells in the presence of vehicle $\left(0.01 \%\right.$ DMSO) or the selective IKK $\beta$ inhibitors IKK $\beta^{\text {III }}$ or IKK $\beta^{\mathrm{V}}(1 \mu \mathrm{M})$. Representative photomicrographs of osteoblast cultures from the experiment are shown in panel d, right. Data are mean $\pm \mathrm{SD}, * * p<0.01$ from vehicle

and mouse breast cancer cells. Treatment of mouse calvarial osteoblasts with $\mathrm{IKK} \beta^{\mathrm{III}}$ or IKK $\beta^{\mathrm{V}}(1.0 \mu \mathrm{M})$ increased alkaline phosphatase activity within 24 h (Fig. 3c), without affecting cell viability when compared to vehicle-treated control cultures (data not shown). Prolonged exposure to these agents enhanced bone nodule formation after 21 days 
(Fig. 3d) $(p<0.01)$. Representative photomicrographs of bone nodule formation from the experiment described are shown in Fig. 3d, right.

\section{Inhibition of IKK $\beta$ in Bone Cells Reduces Breast Cancer-Induced IKB Phosphorylation}

Mechanistic studies in osteoclast precursors showed that exposure to the selective IKK $\beta$ inhibitors IKK $\beta^{\text {III }}$ or IKK $\beta^{\mathrm{V}}$ $(10 \mu \mathrm{M})$ for 1 -h prior reduced I $\mathrm{B}$ phosphorylation induced by MDA-231 or 4T1 conditioned medium after $15 \mathrm{~min}$ and RANKL (100 ng/ml) after 5 min (Fig. 4a). Similar inhibition of I $\mathrm{B}$ phosphorylation was observed in calvarial osteoblasts exposed to MDA-231 conditioned medium for $15 \mathrm{~min}$ (Fig. 4b).

\section{In Vivo Inhibition of IKK $\beta$ Reduces Breast Cancer-Induced Osteoclast and Enhances Osteoblast Number}

Using the intra-tibial 4T1 model of local osteolysis, we validated the effects of the selective IKK $\beta$ inhibitor IKK $\beta^{\text {III }}$ on osteoblast and osteoclast changes associated with breast cancer. IKK $\beta^{\mathrm{III}}$ (20 mg/kg/day) was administered in mice 1 day prior to intra-tibial injection of the $4 \mathrm{~T} 1\left(4 \times 10^{3}\right)$ and continued to day 10 (Fig. 5a). Detailed microCT and histomorphometric analysis of bone at the tibial metaphysis showed that IKK $\beta^{\text {III }}$ significantly inhibited osteolytic bone damage (Fig. 5b, c), reduced osteoclast number (Fig. 5d, left panel) and increased osteoblast number (Fig. 5d, right panel).

\section{Discussion}

Bone is a common metastatic site for malignant breast cancer cells, and bone metastases are a cause of morbidity in advanced breast cancer patients [42, 44, 45]. Osteolytic bone metastases in advanced breast cancer patients result from breast cancer cells in the skeleton releasing factors that disrupt the function of osteoclasts and osteoblasts [42, 44, 45]. Various tumour-derived factors regulate breast cancer-induced osteolysis and bone cell activity by activating the canonical IKK/NFKB signalling pathway $[1,14$, $21]$. IKK $\beta$ also plays a key role in the bone remodelling and bone cell activity [1, 19, 21, 22, 24-26, 46] and we have recently shown that inhibition of the IKK $\beta / \mathrm{NF} \kappa \mathrm{B}$ signalling pathway by using the TAK1 inhibitor Celastrol or the proteasome inhibitor Parthenolide reduced the development of osteolysis in a model of bone metastasis [1, 21, 22, 27].

Cells of the tumour microenvironment in the skeleton, particularly osteoclasts and osteoblasts, play a critical role in the regulation of breast cancer-induced osteolysis $[42,43]$. However, previous studies that have implicated IKK $\beta$ in the regulation of osteolytic breast cancer metastasis were performed in immunodeficient mice treated with agents that indirectly inhibit the canonical IKK $\beta$ activity $[1,21,22,27]$. To examine the contribution of IKK $\beta$ in osteoblasts and osteoclasts to breast cancer-osteolysis, we utilised the verified IKK $\beta$ inhibitors IKK $\beta^{\mathrm{III}}$ or IKK $\beta^{\mathrm{V}}$ [28-30] together with a number of in vivo, ex vivo and in vitro experiments using immunocompetent
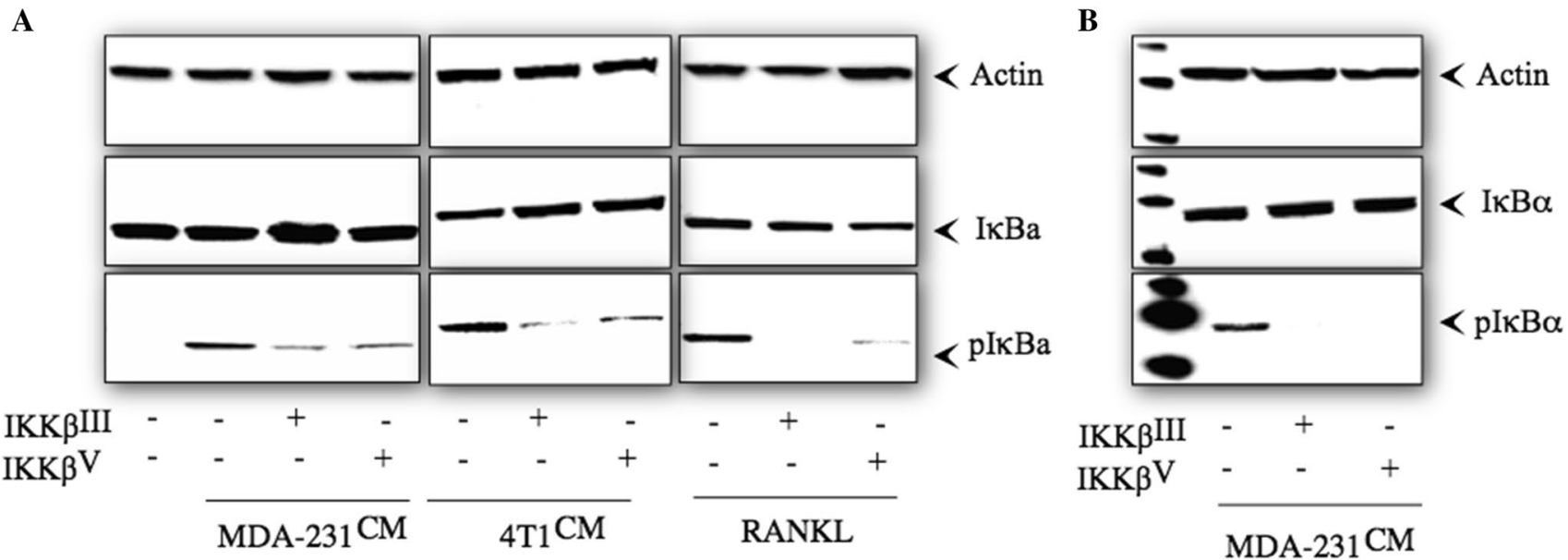

Fig. 4 The selective IKK $\beta$ inhibitors IKK $\beta$ III or IKK $\beta$ V reduce breast cancer-induced I $\mathrm{K} \mathrm{B} \alpha$ phosphorylation in osteoclasts and osteoblasts. a Western blot analysis of total and phosphorylated of I $\mathrm{B}$ and actin in M-CSF dependent pre-osteoclasts after exposure to $\mathrm{CM}$ from human MDA-231 (left) and 4T1 (middle) breast cancer cells $(20 \% \mathrm{v} / \mathrm{v})$ and RANKL $(100 \mathrm{ng} / \mathrm{ml})$ in the presence and absence of the selective IKK $\beta$ inhibitors IKK $\beta^{\mathrm{III}}$ or IKK $\beta^{\mathrm{V}}(10 \mu \mathrm{M})$. b Western blot analysis of total and phosphorylated $\mathrm{I} \kappa \mathrm{B} \alpha$ and actin in mouse calvarial osteoblasts after exposure to $\mathrm{CM}$ from human MDA-231 breast cancer cells $(20 \% \mathrm{v} / \mathrm{v})$ in the presence and absence of the selective IKK $\beta$ inhibitors IKK $\beta^{\text {III }}$ or IKK $\beta^{\mathrm{V}}(10 \mu \mathrm{M})$ 
A

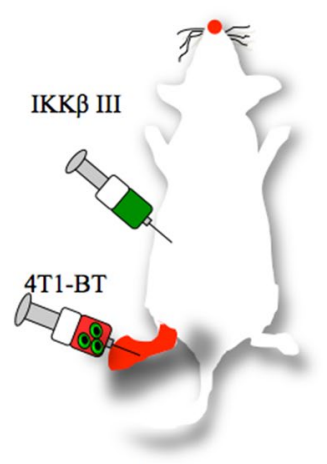

$\mathrm{BALB} / \mathrm{c}$ immunocompetent mouse ( 8 weeks old)
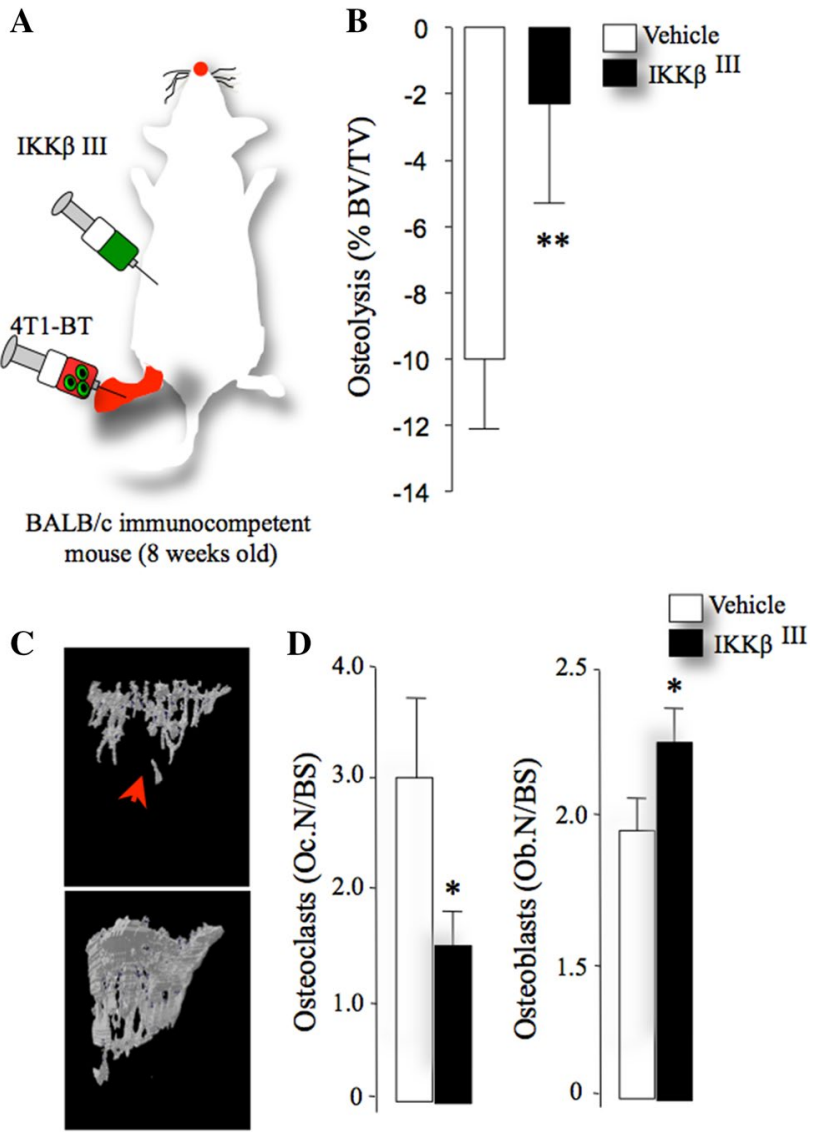

Fig. 5 Selective IKK $\beta$ inhibition reduces breast cancer-induced osteolysis in vivo. a Graphic representation of intra-tibial injection of the mouse breast cancer cells $4 \mathrm{~T} 1$ in immune-competent BALB/c mice pre-treated with vehicle (DMSO/PBS: 0.01:10) or IKK $\beta^{\text {III }}$ $(20 \mathrm{mg} / \mathrm{kg} /$ day) for 12 days $(n=7)$. b Total bone volume (BV/TV) in tibial metaphysis of mice from the experiment described in panel a. c Representative photomicrographs of microCT scans of bone from the experiment described in panels a, b. Arrowhead denotes osteolysis. d, e In vivo number of osteoclasts (Oc.N/BS, left) and osteoblasts (Ob.N/BS, right) per bone surface (BS) from the experiment described in panels a-c. Values are mean $\pm \mathrm{SD} ; * p<0.05$ and $* * p<0.01$ from vehicle plus breast cancer cells

mice, organs and cells. An advantage of this approach is that the tumour microenvironment in the skeleton is not immunocompromised.

Our present results showed that pharmacological inhibition of IKK $\beta$ in host cells reduced breast cancer-induced osteolysis by disrupting breast cancer cell crosstalk with osteoblasts and osteoclasts. The evidence for osteoblastspecific IKK $\beta$ in these processes comes from the experiments that demonstrated that pre-exposure of osteoblasts to IKK $\beta$ inhibitors tested significantly reduced breast cancer-induced osteoclast formation in osteoblast-osteoclast co-cultures. Breast cancer cells secrete various factors that increase RANKL and inhibit OPG expression by osteoblasts. Mechanistic studies in osteoblasts confirmed the

role of osteoblast-specific IKK $\beta$ in the reciprocal interaction between osteoblast and breast cancer cells by showing that pre-exposure of osteoblasts to IKK $\beta$ inhibitors reduced RANKL and OPG production by osteoblasts and these effects were accompanied with significant inhibition of ІкB phosphorylation.

Breast cancer cells promote osteolysis by directly stimulating osteoclast formation [12, 13, 43, 47]. Studies in osteoclast cultures showed that selective pharmacological inhibition of IKK $\beta$ inhibited both breast cancer- and RANKL-induced osteoclast formation and caused osteoclast apoptosis in mature osteoclast cultures. This confirms that selective inhibition of IKK $\beta$ in mature osteoclasts and their precursors inhibits osteoclast formation and survival acting directly on osteoclasts and their precursors. Significant inhibition of osteoclast number was also observed in mice pre-treated with IKK $\beta^{\mathrm{III}}$ prior to injection with $4 \mathrm{~T} 1$ cells. It is important to note, however, that both IKK $\beta$ inhibitors tested prevented osteoclastic bone resorption in vitro but these effects were likely due to induction of apoptosis and cell death rather than a specific effect on osteoclast function (data not shown). Further mechanistic studies in mature osteoclasts confirmed the mechanism of action by which IKK $\beta^{\mathrm{III}}$ and $\operatorname{IKK} \beta^{\mathrm{V}}$ exerted their anti-osteoclast effects by preventing RANKL-induced IкB phosphorylation and partial inhibition of these same pathways when activated with tumour-derived factors from the human MDA-231 breast cancer cells. Nonspecific effects in M-CSF signalling were excluded by the fact that these agents did not inhibit M-CSF-induced signalling (data not shown) or cell viability in cultures of M-CSFdependent osteoclast precursors (data not shown).

The treatment of breast cancer-associated bone disease is predominantly based on drugs that inhibit osteoclast formation and function and induce mature osteoclast apoptosis [42, 44, 45]. Whilst osteoclast inhibitors such as Bisphosphonates and Denosumab have been shown to be effective in the secondary prevention of skeletal-related events associated with various cancers including breast cancer [48-50], these agents have no significant impact on bone formation [48, 51].

Breast cancer cells in bone promote osteolysis by inhibiting osteoblast differentiation [12, 13, 43, 47] and previous studies reported that inhibition of IKK-mediated NFKB activity in osteoblasts increased osteoblast differentiation in vitro and promoted bone formation in vivo [19, 21, 22, 24-26]. Our current results expand and complement these observations by showing that selective inhibition of IKK $\beta$ kinase activity in osteoblasts was accompanied with marked increase in the ability of calvarial osteoblasts to differentiate and to form bone nodule in vitro. Together with the increase in osteoblast number that we observed in vivo, our in vitro data demonstrate that targeted inhibition of IKK $\beta$ in osteoblasts enhances their ability to 
mature even in the presence of breast cancer-derived factors. We, and others, have previously reported that inhibition of NFKB activity reduced bone loss through inhibition of osteoclast bone resorption and stimulation of osteoblast activity in inflammation- and ovariectomy-induced bone loss [19, 22, 24-26]. Our current data complement these studies and demonstrate that inhibition of IKK $\beta$ in the tumour microenvironment inhibited osteoclast activity, enhanced osteoblast differentiation and reduced bone loss associated with osteolytic breast cancer metastasis.

In conclusion, our present findings suggest that inhibition of the IKK $\beta / \mathrm{NF} \kappa \mathrm{B}$ signalling in the bone microenvironment may have a potential role in protecting the skeleton from the osteolysis associated with breast cancer. In elucidating the mechanism of breast cancer-induced osteolysis, these findings together suggest that disrupting breast cancer cell-osteoblast-osteoclast communications through inhibition of IKK $\beta$ kinase activity in bone cells might protect against breast cancer-induced osteolysis by inhibiting excessive osteoclast formation and promoting osteoblast differentiation. When combined with previous studies, our pharmacological studies demonstrate that disruption of breast cancer- and RANKL-induced IKK $\beta$ activity in cells of the bone metastatic microenvironment resulted in pro-bone gain and anti-bone loss network of effects. These findings may have important clinical implications in raising the possibility that inhibitors of the canonical NFкB pathway, as osteoanabolics may have advantages over conventional anti-resorptive agents such as bisphosphonate [49, 52] and Denosumab [53, 54] for the treatment of osteolysis in advanced breast cancer patients given that they may encourage new bone regeneration. However, the potential use of NFKB inhibitors in cases of breast cancer with bone metastases needs to be carefully explored so that any treatment regime would take into consideration and exploit both, their cell-autonomous effects in the bone microenvironment and their direct effects on tumour. For that, further studies are needed and ongoing.

Acknowledgements These studies were supported in part by a Moray Endowment Fund and Cancer Research UK Development Fund (Edinburgh Cancer Research Centre, University of Edinburgh).

Author Contributions SM and RTB: experiment and analysis; PM: conception, donation of material and editing and AII-conception, experimental, analysis, editing and writing.

\section{Compliance with Ethical Standards}

Conflict of interest Patrick Mollat is an employee of Galapagos SASU (102 Avenue Gaston Roussel, 93230 Romainville, France). Silvia Marino, Ryan T. Bishop and Aymen I. Idris declare that they have no conflict of interest.
Human and Animal Rights and Informed Consent All procedures involving mice and their care were approved by and performed in compliance with the guidelines of Institutional Animal Care and Use Committee of University of Edinburgh (Scotland, UK).

Open Access This article is distributed under the terms of the Creative Commons Attribution 4.0 International License (http://creativeco mmons.org/licenses/by/4.0/), which permits unrestricted use, distribution, and reproduction in any medium, provided you give appropriate credit to the original author(s) and the source, provide a link to the Creative Commons license, and indicate if changes were made.

\section{References}

1. Park BK, Zhang H, Zeng Q, Dai J, Keller ET, Giordano T, Gu K, Shah V, Pei L, Zarbo RJ, McCauley L, Shi S, Chen S, Wang CY (2007) NF-kappaB in breast cancer cells promotes osteolytic bone metastasis by inducing osteoclastogenesis via GM-CSF. Nat Med 13:62-69

2. Lee DF, Hung MC (2008) Advances in targeting IKK and IKKrelated kinases for cancer therapy. Clin Cancer Res 14:5656-5662

3. Clement JF, Meloche S, Servant MJ (2008) The IKK-related kinases: from innate immunity to oncogenesis. Cell Res 18:889-899

4. Gasparian AV, Yao YJ, Kowalczyk D, Lyakh LA, Karseladze A, Slaga TJ, Budunova IV (2002) The role of IKK in constitutive activation of NF-kappaB transcription factor in prostate carcinoma cells. J Cell Sci 115:141-151

5. Jourdan M, Moreaux J, Vos JD, Hose D, Mahtouk K, Abouladze M, Robert N, Baudard M, Reme T, Romanelli A, Goldschmidt H, Rossi JF, Dreano M, Klein B (2007) Targeting NF-kappaB pathway with an IKK2 inhibitor induces inhibition of multiple myeloma cell growth. Br J Haematol 138:160-168

6. Luo JL, Tan W, Ricono JM, Korchynskyi O, Zhang M, Gonias SL, Cheresh DA, Karin M (2007) Nuclear cytokine-activated IKKalpha controls prostate cancer metastasis by repressing Maspin. Nature 446:690-694

7. Kishida Y, Yoshikawa H, Myoui A (2007) Parthenolide, a natural inhibitor of Nuclear Factor-kappaB, inhibits lung colonization of murine osteosarcoma cells. Clin Cancer Res 13:59-67

8. Crawford A, Nahta R (2011) Targeting Bcl-2 in herceptin-resistant breast cancer cell lines. Curr Pharmacogenom Personal Med 9:184-190

9. Wu L, Shao L, An N, Wang J, Pazhanisamy S, Feng W, HauerJensen M, Miyamoto S, Zhou D (2011) IKKbeta regulates the repair of DNA double-strand breaks induced by ionizing radiation in MCF-7 breast cancer cells. PLoS ONE 6:e18447

10. Tezil T, Bodur C, Kutuk O, Basaga H (2012) IKK-beta mediates chemoresistance by sequestering FOXO3; a critical factor for cell survival and death. Cell Signal 24:1361-1368

11. Oida K, Matsuda A, Jung K, Xia Y, Jang H, Amagai Y, Ahn G, Nishikawa S, Ishizaka S, Jensen-Jarolim E, Matsuda H, Tanaka A (2014) Nuclear factor-kB plays a critical role in both intrinsic and acquired resistance against endocrine therapy in human breast cancer cells. Sci Rep 4:4057

12. Yoneda T, Hiraga T (2005) Crosstalk between cancer cells and bone microenvironment in bone metastasis. Biochem Biophys Res Commun 328:679-687

13. Zhang XH, Jin X, Malladi S, Zou Y, Wen YH, Brogi E, Smid M, Foekens JA, Massague J (2013) Selection of bone metastasis seeds by mesenchymal signals in the primary tumor stroma. Cell 154:1060-1073 
14. Karin M (2008) The IkappaB kinase-a bridge between inflammation and cancer. Cell Res 18:334-342

15. Kobayashi N, Kadono Y, Naito A, Matsumoto K, Yamamoto T, Tanaka S, Inoue J (2001) Segregation of TRAF6-mediated signaling pathways clarifies its role in osteoclastogenesis. EMBO J 20:1271-1280

16. Lomaga MA, Yeh WC, Sarosi I, Duncan GS, Furlonger C, Ho A, Morony S, Capparelli C, Van G, Kaufman S, van der HA, Itie A, Wakeham A, Khoo W, Sasaki T, Cao Z, Penninger JM, Paige CJ, Lacey DL, Dunstan CR, Boyle WJ, Goeddel DV, Mak TW (1999) TRAF6 deficiency results in osteopetrosis and defective interleukin-1, CD40, and LPS signaling. Genes Dev 13:1015-1024

17. Naito A, Azuma S, Tanaka S, Miyazaki T, Takaki S, Takatsu K, Nakao K, Nakamura K, Katsuki M, Yamamoto T, Inoue J (1999) Severe osteopetrosis, defective interleukin-1 signalling and lymph node organogenesis in TRAF6-deficient mice. Genes Cells 4:353-362

18. Chaisson ML, Branstetter DG, Derry JM, Armstrong AP, Tometsko ME, Takeda K, Akira S, Dougall WC (2004) Osteoclast differentiation is impaired in the absence of inhibitor of kappa $\mathrm{B}$ kinase alpha. J Biol Chem 279:54841-54848

19. Ruocco MG, Maeda S, Park JM, Lawrence T, Hsu LC, Cao Y, Schett G, Wagner EF, Karin M (2005) I \{kappa\}B kinase (IKK) \{beta\}, but not IKK $\{$ alpha\}, is a critical mediator of osteoclast survival and is required for inflammation-induced bone loss. J Exp Med 201:1677-1687

20. Idris AI, Greig IR, Bassonga-Landao E, Ralston SH, t Hof RJ (2009) Identification of Novel biphenyl carboxylic acid derivatives as novel antiresorptive agents that do not impair parathyroid hormone-induced bone formation. Endocrinology 150:5-13

21. Idris AI, Libouban H, Nyangoga H, Landao-Bassonga E, Chappard D, Ralston SH (2009) Pharmacologic inhibitors of IkappaB kinase suppress growth and migration of mammary carcinosarcoma cells in vitro and prevent osteolytic bone metastasis in vivo. Mol Cancer Ther 8:2339-2347

22. Idris AI, Krishnan M, Simic P, Landao-Bassonga E, Mollat P, Vukicevic S, Ralston SH (2010) Small molecule inhibitors of I \{kappa\}B kinase signaling inhibit osteoclast formation in vitro and prevent ovariectomy-induced bone loss in vivo. FASEB J 24:4545-4555

23. Idris AI, Coste E, Greig IR, Ralston SH, van't Hof RJ (2010) The biphenyl-carboxylate derivative ABD328 is a novel orally active antiresorptive agent. Calcif Tissue Int 87:525-532

24. Otero JE, Dai S, Alhawagri MA, Darwech I, Abu-Amer Y (2010) IKKbeta activation is sufficient for RANK-independent osteoclast differentiation and osteolysis. J Bone Miner Res 25:1282-1294

25. Chang J, Wang Z, Tang E, Fan Z, McCauley L, Franceschi R, Guan K, Krebsbach PH, Wang CY (2009) Inhibition of osteoblastic bone formation by nuclear factor-kappaB. Nat Med $15: 682-689$

26. Alles N, Soysa NS, Hayashi J, Khan M, Shimoda A, Shimokawa H, Ritzeler O, Akiyoshi K, Aoki K, Ohya K (2010) Suppression of NF-kappaB increases bone formation and ameliorates osteopenia in ovariectomized mice. Endocrinology 151:4626-4634

27. Marino S, Bishop RT, Logan JG, Mollat P, Idris AI (2017) Pharmacological evidence for the bone-autonomous contribution of the NFkappaB/beta-catenin axis to breast cancer related osteolysis. Cancer Lett 410:180-190

28. Kamon J, Yamauchi T, Muto S, Takekawa S, Ito Y, Hada Y, Ogawa W, Itai A, Kasuga M, Tobe K, Kadowaki T (2004) A novel IKKbeta inhibitor stimulates adiponectin levels and ameliorates obesity-linked insulin resistance. Biochem Biophys Res Commun 323:242-248

29. Tanaka A, Konno M, Muto S, Kambe N, Morii E, Nakahata T, Itai A, Matsuda H (2005) A novel NF-kappaB inhibitor, IMD-0354, suppresses neoplastic proliferation of human mast cells with constitutively activated c-kit receptors. Blood 105:2324-2331

30. Burke JR, Pattoli MA, Gregor KR, Brassil PJ, MacMaster JF, McIntyre KW, Yang X, Iotzova VS, Clarke W, Strnad J, Qiu Y, Zusi FC (2003) BMS-345541 is a highly selective inhibitor of I kappa B kinase that binds at an allosteric site of the enzyme and blocks NF-kappa B-dependent transcription in mice. J Biol Chem 278:1450-1456

31. Rucci N, Capulli M, Ventura L, Angelucci A, Peruzzi B, Tillgren V, Muraca M, Heinegard D, Teti A (2013) Proline/arginine-rich end leucine-rich repeat protein $\mathrm{N}$-terminus is a novel osteoclast antagonist that counteracts bone loss. J Bone Miner Res 28:1912-1924

32. Logan JG, Sophocleous A, Marino S, Muir M, Brunton VG, Idris AI (2013) Selective tyrosine kinase inhibition of insulin-like growth factor-1 receptor inhibits human and mouse breast cancer-induced bone cell activity, bone remodeling, and osteolysis. J Bone Miner Res 28:1229-1242

33. Boyce BF, Aufdemorte TB, Garrett IR, Yates AJP, Mundy GR (1989) Effects of interleukin-1 on bone turnover in normal mice. Endocrinology 125:1142-1150

34. Campbell GM, Sophocleous A (2014) Quantitative analysis of bone and soft tissue by micro-computed tomography: applications to ex vivo and in vivo studies. Bone Key Rep 3:564

35. Dempster DW, Compston JE, Drezner MK, Glorieux FH, Kanis JA, Malluche H, Meunier PJ, Ott SM, Recker RR, Parfitt AM (2013) Standardized nomenclature, symbols, and units for bone histomorphometry: a 2012 update of the report of the ASBMR Histomorphometry Nomenclature Committee. J Bone Miner Res 28:2-17

36. Taylor SE, Shah M, Orriss IR (2014) Generation of rodent and human osteoblasts. BoneKEy Rep 3:585

37. Nakayama GR, Caton MC, Nova MP, Parandoosh Z (1997) Assessment of the Alamar Blue assay for cellular growth and viability in vitro. J Immunol Methods 204:205-208

38. Orriss IR, Taylor SE, Arnett TR (2012) Rat osteoblast cultures. Methods Mol Biol 816:31-41

39. van't Hof RJ (2003) Osteoclast formation in the mouse coculture assay. In: Helfrich MH, Ralston SH (eds) Bone research protocols. Humana Press, Totowa, pp 145-152

40. van't Hof RJ, Hocking L, Wright PK, Ralston SH (2000) Nitric oxide is a mediator of apoptosis in the rheumatoid joint. Rheumatology (Oxford) 39:1004-1008

41. Suda T, Takahashi N, Udagawa N, Jimi E, Gillespie MT, Martin TJ (1999) Modulation of osteoclast differentiation and function by the new members of the tumor necrosis factor receptor and ligand families. Endocr Rev 20:345-357

42. Roodman GD (2004) Mechanisms of bone metastasis. N Engl J Med 350:1655-1664

43. Siclari VA, Guise TA, Chirgwin JM (2006) Molecular interactions between breast cancer cells and the bone microenvironment drive skeletal metastases. Cancer Metastas Rev 25:621-633

44. Mundy GR (2002) Metastasis to bone: causes, consequences and therapeutic opportunities. Nat Rev Cancer 2:584-593

45. Coleman RE (2001) Metastatic bone disease: clinical features, pathophysiology and treatment strategies. Cancer Treat Rev 27:165-176

46. Kim JY, Cheon YH, Yoon KH, Lee MS, Oh J (2014) Parthenolide inhibits osteoclast differentiation and bone resorbing activity by down-regulation of NFATc1 induction and c-Fos stability, during RANKL-mediated osteoclastogenesis. BMB Rep 47:451-456

47. Thomas RJ, Guise TA, Yin JJ, Elliott J, Horwood NJ, Martin TJ, Gillespie MT (1999) Breast cancer cells interact with osteoblasts to support osteoclast formation. Endocrinology 140:4451-4458

48. Hillner BE, Ingle JN, Berenson JR, Janjan NA, Albain KS, Lipton A, Yee G, Biermann JS, Chlebowski RT, Pfister DG 
(2000) American Society of Clinical Oncology guideline on the role of bisphosphonates in breast cancer. American Society of Clinical Oncology Bisphosphonates Expert Panel. J Clin Oncol 18:1378-1391

49. Berenson JR, Rosen LS, Howell A, Porter L, Coleman RE, Morley W, Dreicer R, Kuross SA, Lipton A, Seaman JJ (2001) Zoledronic acid reduces skeletal-related events in patients with osteolytic metastases. Cancer 91:1191-1200

50. Berenson JR, Lichtenstein A, Porter L, Dimopoulos MA, Bordoni R, George S, Lipton A, Keller A, Ballester O, Kovacs MJ, Blacklock HA, Bell R, Simeone J, Reitsma DJ, Heffernan M, Seaman J, Knight RD, Myeloma Aredia Study Group (1996) Efficacy of pamidronate in reducing skeletal events in patients with advanced multiple myeloma. N Engl J Med 334:488-493

51. Weilbaecher KN, Guise TA, McCauley LK (2011) Cancer to bone: a fatal attraction. Nat Rev Cancer 11:411-425
52. Coleman RE, Marshall H, Cameron D, Dodwell D, Burkinshaw R, Keane M, Gil M, Houston SJ, Grieve RJ, Barrett-Lee PJ, Ritchie D, Pugh J, Gaunt C, Rea U, Peterson J, Davies C, Hiley V, Gregory W, Bell R (2011) Breast-cancer adjuvant therapy with zoledronic acid. N Engl J Med 365:1396-1405

53. Body JJ, Lipton A, Gralow J, Steger GG, Gao G, Yeh H, Fizazi $\mathrm{K}$ (2010) Effects of denosumab in patients with bone metastases, with and without previous bisphosphonate exposure. J Bone Miner Res 25:440-446

54. Nolan E, Vaillant F, Branstetter D, Pal B, Giner G, Whitehead L, Lok SW, Mann GB, Kathleen Cuningham Foundation Consortium for Research into Familial Breast Cancer (kConFab), Rohrbach K, Huang LY, Soriano R, Smyth GK, Dougall WC, Visvader JE, Lindeman GJ (2016) RANK ligand as a potential target for breast cancer prevention in BRCA1-mutation carriers. Nat Med 22:933-939 